\title{
Control of air pollution caused by vehicular emissions
}

\author{
Eliza Gumerova ${ }^{1, *}$, Olga Gamayunova ${ }^{1}$ \\ ${ }^{1}$ Peter the Great St.Petersburg Polytechnic University, Politechnicheskaya 29, St. Petersburg, 195251, \\ Russian Federation
}

\begin{abstract}
Dispersion of air pollutants is caused often by vehicular emissions. It is necessary to define correctly parameters, which influence on emissions. In this article analysis of the parameters and calculations of Saint-Petersburg roads are shown. According to results, measures to improve the air state are defined. Solving of this ecological problem is implementation of development programs of urban public transport, the use of fuel with improved environmental characteristics, the development of electric modes of transport, traffic management methods to increase the capacity of the road and road network in the city.
\end{abstract}

\section{Introduction}

In most cases dispersion of air pollutants is caused by vehicular emissions. The value of emissions often exceeds the maximum allowable concentration in the air in the same way does damage to environment. That is why the rightness of its estimate is becoming more and more essential nowadays. The purpose of the article is to concretize parameters of vehicular emissions and to define measures to decrease dispersion of air pollutants. To reach the goal the following tasks were set:

1. To examine basic processes during the vehicular emissions.

2. Definition the data for calculation of emissions.

3. To plan parametric model for calculation as for singular transport as for traffic flow.

4. Due to parameters to match the measures which allow decreasing influence of highway transport on environment.

\section{Methods}

\subsection{Causes}

The life cycle of vehicle is divided into stages of creation (production and processing of raw materials, production of structural, operational, road-building materials, transportation, and storage), production, use, reconstruction of working capacity and utilization of equipment or structure [1-3].

\footnotetext{
* Corresponding author: eliza_gumerova@mail.ru
} 
Creation includes extraction and processing of raw materials, production of materials, consumable operational materials, which are necessary for its operation.

The stage of production consists of manufacture of components, parts, and transport assembly, construction of engineering structures (road section, bridge, and overpass).

The operational step includes the performance of transport work during the normative service life of vehicle or the use of a section of the road, bridge.

Restoration of working capacity provides for maintenance of the transport object with the detail repair or replace of parts, assemblies, units [4,7].

The stage of utilization of the transport facility involves disassembly (liquidation), processing of parts and components that are unsuitable for restoration, reuse of structural and operational materials at the previous stages of the life cycle of transport facilities or in other areas of activity, waste disposal.

Delivery, transportation and storage are intermediate and apply to both materials and transport objects.

Technological processes at every step of vehicle life cycle are accompanied by energy consumption and emissions of harmful and toxic substances [5]. The main processes that affect the atmospheric air are:

- Thermodynamic processes in engines, technological furnaces and combustion devices of solid, liquid and gaseous fossil fuels for getting electric, thermal energy, steam and compressed air.

- Evaporation, fuel loss, operating fluids, paints and other materials during creation, maintenance and repair of transport equipment.

\subsection{Estimating air pollution related to traffic flow}

The following approach should be used to estimate the concentrations of car emissions in the atmosphere $[6,8,10]$ :

- To consider the value of emissions and fuel consumption at different speeds and in driving cycles of single vehicles in traffic flow.

- Taking into account emissions and fuel consumption caused by traffic flow on certain road parts (on stages and intersections).

- Keeping in mind the concentration of components of automobile emissions in the surface layer of the atmosphere on the considered section of the highway.

The initial data needed to calculate the amount of air pollutants cause by vehicular emissions can be divided into two groups [9]:

1. Characteristics of road and transport conditions.

2. Weather and climatic conditions of operational area of vehicles.

Vehicular emissions consist of pollutants while heating engine $\left(E_{1}\right)$, additional emission during engine reaches optimal temperature characteristics $\left(E_{2}\right)$ and while left driving time $\left(\mathrm{E}_{3}\right)$ :

$$
E=E_{1}+E_{2}+E_{3}
$$

The value of $E_{1}$ characterizes the initial operating parameters of the internal combustion engine.

$\mathrm{E}_{2}$ defines the movement until the engine reaches optimum temperature characteristics.

The third parameter refers to release process of pollutants while the engine and the vehicle pollution reduction system have reached the optimum operating temperature.

The main factors affecting the amount of emissions are the load capacity (power of engine), the type of used fuel, speed, compliance with environmental standards. 
Moreover, the following correctives should be considered: road slope; degree of vehicular load; state of the exhaust gas neutralizer; temperature; tightening of environmental requirements.

Thus, the following dependency can be used for singular vehicle (2):

$$
\mathrm{E}^{*}=n(u) * A * B * C * D
$$

where $E^{*}$ is the corrected number of emissions, $g / \mathrm{km}$; $\mathrm{n}(\mathrm{u})$ is the dependence of emissions and average speed; A, B, C, D - coefficients for slope, degree of loading, mileage and temperature.

Two approaches can be used to estimate emissions cause by traffic flow: giving a meaning to the influence of vehicles on each other during the flow and taking into account such influence. In the first case, the emissions of individual vehicles in flow on the road section are simply summed, in the second - the movement of individual cars in this aggregate is tracked.

\section{Results and Discussion}

\subsection{Air quality in Saint-Petersburg}

The level of air pollution in Saint-Petersburg is determined by emissions of pollutants into the air from stationary and mobile sources [11,13-15]. The greatest contribution (85\%) to air pollution is made by road transport. Diagram 1 shows the change in traffic intensity during the year on federal and regional roads.

Diagram 1. Changes in traffic flow during the year.

$$
\mathrm{N}, \text { aut/days } 20000
$$

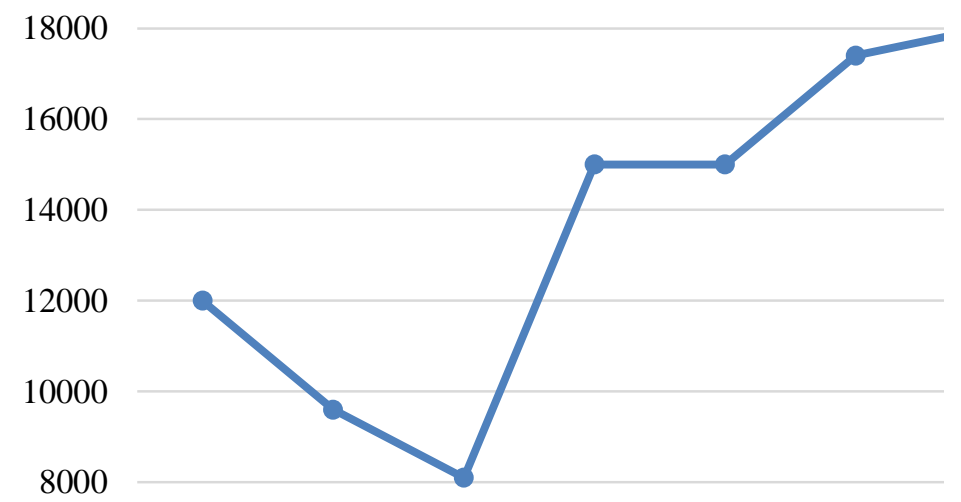

The number of vehicles per day reaches 18 thousands, so it is imperative to assess the emissions of pollutants into the atmosphere for making measures to improve the air quality. Table 1 shows the intensity of traffic in Saint-Petersburg [12].

Table 1. The intensity of traffic flow in rush hour.

\begin{tabular}{|c|c|c|c|c|c|c|}
\hline \multirow{2}{*}{ Destination } & \multicolumn{4}{|c|}{ The automobile intensity due to its type per hour } & \multirow{2}{*}{$\begin{array}{c}\text { Total quantity } \\
\text { during the hour }\end{array}$} \\
\cline { 2 - 7 } & Bus & Automobile & Lorry & Truck & $\begin{array}{c}\text { Heavy } \\
\text { truck }\end{array}$ & 1941 \\
\hline Lesnoy pr. & 95 & 1587 & 195 & 42 & 22 & 194 \\
\hline
\end{tabular}




\begin{tabular}{|c|c|c|c|c|c|c|}
\hline \multirow[b]{2}{*}{ Destination } & \multicolumn{5}{|c|}{ The automobile intensity due to its type per hour } & \multirow[b]{2}{*}{$\begin{array}{l}\text { Total quantity } \\
\text { during the hour }\end{array}$} \\
\hline & Bus & Automobile & Lorry & Truck & $\begin{array}{c}\text { Heavy } \\
\text { truck }\end{array}$ & \\
\hline $\begin{array}{c}\text { Ispytatelei } \\
\text { prospect }\end{array}$ & 149 & 2578 & 439 & 76 & 12 & 3254 \\
\hline $\begin{array}{c}\text { Bogatyrsky } \\
\text { pr. }\end{array}$ & 122 & 2448 & 259 & 82 & 16 & 2927 \\
\hline
\end{tabular}

Using the above data, we will calculate the emissions of pollutants from moving vehicles.

The release of i-pollutant $(\mathrm{g} / \mathrm{sec})$ by traffic flow on a section of a road with fixed length $\mathrm{L}(\mathrm{km})$ is determined by the formula:

$$
M_{L i}=\frac{L}{1200} * \sum_{1}^{k} M_{k i}^{L} * G_{k} * r_{V_{k i}}
$$

where $M_{k i}^{L}(\mathrm{~g} / \mathrm{km})$ - brake specific exhaust emission of i-substance by cars of k-group for the urban operational conditions, determined in accordance with table 2;

$\mathrm{k}$ - number of car groups;

$G_{k}$ - the actual maximum traffic intensity, i.e. the number of cars of each of the kgroups, passing through a fixed section of the selected road in a unit of time in both directions along all road lanes;

$r_{V_{k i}}$ - the correction factor which considers the average speed of traffic flow $\left(V_{k i}, \mathrm{~km} /\right.$ h) on the selected highway (or its section), determined due to table 3;

$\mathrm{L}(\mathrm{km})$ - the length of road or its section (the length of the car queue and the length of intersection zone is excluded).

Table 2. Mileage emission values $(\mathrm{g} / \mathrm{km})$ for different vehicle groups.

\begin{tabular}{|c|c|c|c|c|c|c|c|c|}
\hline \multirow{2}{*}{$\begin{array}{c}\text { Name of } \\
\text { transport } \\
\text { category }\end{array}$} & \multirow{2}{*}{ No. } & $\mathrm{CO}$ & \multicolumn{6}{|c|}{ Emissions, g/km } \\
\cline { 4 - 9 } & & $\mathrm{NO}$ & $\mathrm{CH}$ & Soot & $\mathrm{SO}_{2}$ & Formaldehyde & Benzpyren \\
\hline Automobiles & $\mathrm{I}$ & 1.5 & 0.5 & 0.3 & 0.005 & 0.012 & 0.0018 & $0.2^{*} 10^{-6}$ \\
\hline $\begin{array}{c}\text { Lorries } \\
\text { (weight to } \\
3.5 \mathrm{t} \text { ) }\end{array}$ & II & 8.4 & 1.8 & 2.1 & 0.034 & 0.026 & 0.0078 & $0.6^{*} 10^{-6}$ \\
\hline $\begin{array}{c}\text { Trucks } \\
\text { (weight } \\
\text { from 3.5 to } \\
12 \mathrm{t})\end{array}$ & III & 6.8 & 6.4 & 4.8 & 0.38 & 0.048 & 0.021 & $1.8^{*} 10^{-6}$ \\
\hline $\begin{array}{c}\text { Heavy } \\
\text { trucks } \\
\text { (weight } \\
\text { from 12 t) }\end{array}$ & IV & 7.3 & 7.6 & 6.0 & 0.45 & 0.07 & 0.024 & $2.2^{*} 10^{-6}$ \\
\hline $\begin{array}{c}\text { Buses } \\
\text { (weight } \\
\text { from 3.5 t) }\end{array}$ & V & 5.2 & 4.8 & 4.2 & 0.28 & 0.04 & 0.018 & $1.8^{*} 10^{-6}$ \\
\hline
\end{tabular}


Table 3. Coefficients $r_{V_{k i}}$, considering changes of emissions amount depending on the average speed.

\begin{tabular}{|c|c|c|c|c|c|c|c|c|c|}
\hline & \multicolumn{10}{|c|}{ Speed (V, km/hour) } \\
\cline { 2 - 10 } & 30 & 35 & 40 & 45 & 50 & 60 & 75 & 80 & 100 \\
\hline$r_{V_{k 1}}$ & 1.0 & 0.88 & 0.75 & 0.63 & 0.5 & 0.3 & 0.45 & 0.5 & 0.65 \\
\hline$r_{V_{k 1}}\left(N_{X}\right)$ & 1.0 & 1.0 & 1.0 & 1.0 & 1.0 & 1.0 & 1.0 & 1.0 & 1.0 \\
\hline
\end{tabular}

Thus, the emission of nitric oxide on Lesnoy prospect is equaled to $7.82 \mathrm{~g} / \mathrm{km}$, on Ispytatelei prospect the value reaches $13.48 \mathrm{~g} / \mathrm{km}$, Bogatyrskiy prospect $-19.2 \mathrm{~g} / \mathrm{km}$.

Table 4 shows data about emissions of pollutants from road transport over the past 5 years [16].

Table 4. Vehicular emissions of air pollutants in Saint-Petersburg for 2013-2017 in thousand tons.

\begin{tabular}{|c|c|c|c|c|c|c|}
\hline & Total & Solid & $\mathrm{SO}_{2}$ & $\mathrm{CO}$ & $\mathrm{NO}_{\mathrm{X}}$ & $\mathrm{CH}_{\mathrm{X}}$ \\
\hline 2013 & 464.3 & 0.8 & 2.2 & 374.4 & 38.9 & 2.0 \\
\hline 2014 & 441.7 & 0.8 & 2.1 & 356.1 & 37.2 & 1.9 \\
\hline 2015 & 446.7 & 0.8 & 2.2 & 360.1 & 37.7 & 1.9 \\
\hline 2016 & 447.8 & 0.8 & 2.1 & 361.1 & 37.6 & 1.9 \\
\hline 2017 & 470.8 & 0.9 & 2.3 & 379.8 & 39.6 & 2.0 \\
\hline
\end{tabular}

Diagram 2. Dispersion of air pollutants by vehicular emissions in Saint-Petersburg for 2013-2017.

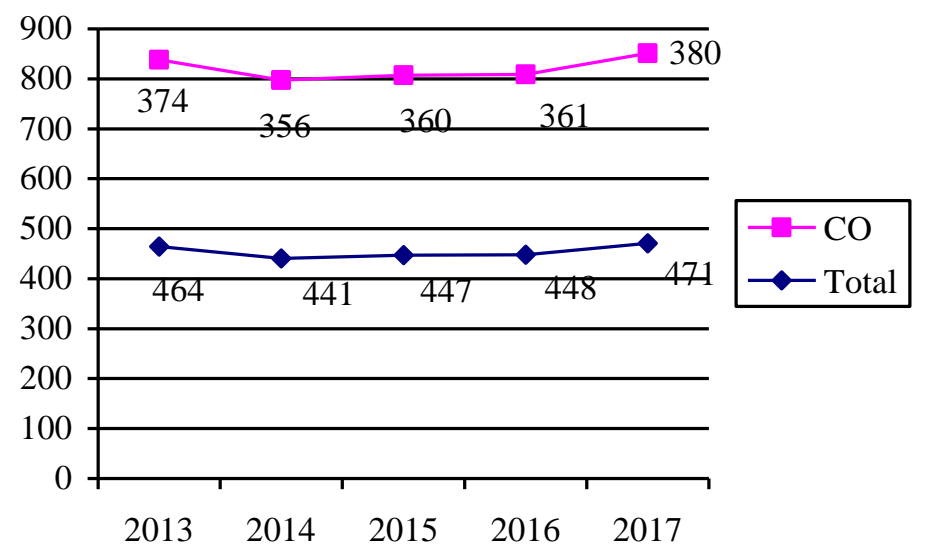

According to diagram 2, the conclusion about increase of emissions caused by vehicle during past 5 years can be made.

The official data about quantity of transport for the past 5 years are given in table 5 [17].

Table 5. Registered quantity of transport for 2013-2017 years.

\begin{tabular}{|c|c|c|c|c|}
\hline & Automobiles & Lorries & Buses & Total \\
\hline 2013 & 1741267 & 220067 & 21513 & 1982847 \\
\hline 2014 & 1636336 & 213123 & 19838 & 1869297 \\
\hline 2015 & 1638183 & 217738 & 20221 & 1876142 \\
\hline 2016 & 1676379 & 214003 & 19659 & 1910041 \\
\hline
\end{tabular}




\begin{tabular}{l|l|l|l|l|}
2017 & 1710811 & 223662 & 29798 & 196427 \\
\hline
\end{tabular}

The vehicle number in comparison with the previous year is enlarged by 2.8 percent. That is why the increase of vehicular emissions is identified.

\subsection{Measures for reduction the environmental impact of transport}

The main measure to improve the atmosphere state in Saint-Petersburg is implementation of development programs of urban public transport, including the equipping of buses with the emission of pollutants not lower than Euro-6, the use of fuel with improved environmental characteristics, the development of electric modes of transport, including trolleybuses and trams, the development of algorithms and technical means of environmental monitoring at transport facilities and adjacent territories, traffic management methods to increase the capacity of the road and road network in the city [18-20,23].

Furthermore, additional actions to reduce air pollutions from vehicles are the following: - Improvement of the regulatory base to ensure environmental safety (sustainable development) of industry and transport.

- Creation of environmentally friendly structures of transport facilities, operational, structural, construction materials, technologies of their production.

- Development of resource-saving technologies to protect the environment from transport pollution.

The main activities are analyzed in more detail.

1. Improvement of engines is carried out to ensure the most complete combustion of fuel $[21,22]$. The engines based on weakest mixture, multi-valve system of redistribution, fuel injection instead of carbureted air-fuel mixture, electronic ignition. Modern carburetors use the start-up and warming machines. The economizer of forced idling is used in the braking modes of the engine.

Recycling is used for reducing emissions of nitrogen oxides. This process involves bypass of the exhaust gas from the exhaust pipe to the inlet. During the recycling the combustion temperature reduces, and quantity of nitrogen oxides is becoming less. In this regard, the electronic ignition system, optimizing the operation of the engine in all modes are very prospective. Technological rules are tightened, manufacturing accuracy of all mechanisms is increased. Therefore, cars of leading companies in Europe and the United States emit harmful substances in 10-16 times less than 30 years ago. New European and Japanese engines have been working on weakest mixtures from 1:20 to 1:40. Russian scientists have created fundamentally new technology of the automobile engine, which has no analogues in the world. It is based on molecular mixture with $100 \%$ gasoline evaporation. The exhaust of the engine with this mixture is almost clean.

2. The neutralizers of the exhaust gases [24-27]. Nowadays there are three-component catalysts that extract nitrogen oxides. This system is connected to the car exhaust system. Post-combustion of gases happens at $600-800^{\circ} \mathrm{C}$. The block is made of ceramic or metal strips with the addition of palladium or rhodium. In general, the mechanism of catalysis is described by the following chemical equation (4).

$$
\mathrm{CO}+\mathrm{C}_{\mathrm{n}} \mathrm{H}_{\mathrm{m}}+\mathrm{NO}_{\mathrm{X}} \rightarrow \mathrm{CO}_{2}+\mathrm{N}_{2}+\mathrm{H}_{2} \mathrm{O}
$$

Consumption of platinum for one catalyst is 1.0-1.5 g. Operational condition of the catalyst is the use of gasoline which contains no tetraethyl lead, because lead deactivates the catalyst.

Russian scientists have created their own neutralizer, which purifies the emission by 90 percent, and its price is twice lower because of not containing any expensive metals [28]. 
Soot filters and oxidation catalysts are set on diesel engines for purification of exhaust gas. The filter is a monolithic block with a large number of parallel channels with porous walls muffled from one end. The exhaust gases are cleaned of soot by passing through porous walls from one channel to another. Filters are made of foam ceramics and foam metal. The capture process is complicated by the fact that the size of almost half of the particles is less than 0.5 micrometers.

3. Use of alternative fuels [29-31].

3.1. Using the gas, the concentration of carbon and nitrogen oxides in the exhaust of the engine is much lower than that of the gasoline engine, even equipped with a modern threecomponent catalytic converter with a closed circuit. Gas fuel does not contain lead or even sulfur compounds.

The gas is perfectly mixed with air, evenly distributed over the engine cylinders, which guarantees its complete combustion and high fuel efficiency. In addition to this, gas fuel prolongs the life of the car engine by 1.5 times. Also, gas does not break the oil film between the rubbing parts, as gasoline does.

3.2. The exhaust gases, which are using methanol or ethanol during work, contain carbon dioxide in 5 times less, than the gases working on gasoline. There are no emissions of CO, almost no soot and toxic substances, except formaldehyde. The main disadvantage of methanol is its lower energy content: the unit of its volume contains by 2 times less energy than the unit of gasoline or diesel fuel. This means that the fuel tank for methanol is bigger and heavier. The most prospective raw material for methanol is coal, and any biomass for ethanol. Ethanol is more expensive than methanol. Nowadays this fuel is used in South America.

\subsection{Hydrogen.}

The use of hydrogen can solve the problem of air pollution by vehicle and energy. The characteristics of hydrogen as a motor fuel are unique. Hydrogen is produced using the conversion of liquid and gaseous fuels and hydrolysis of water. The hydrogen storage, fuel cell and electric motor for future hydrogen car have already been developed. The energy transformation takes place on polymer membranes at the boiling point of water. Prototypes of such cars have been existed, but they are expensive and not perfect enough.

4. Creation of electric vehicles [32].

Electric car does not pollute the atmosphere, it is not noisy as other cars. Its main problem is a short service life of batteries and low power consumption. In the United States there is an active work on the creation of sodium-lithium batteries. Hybrid systems with combination of diesel and electric engines are being invented in Japan.

\section{Conclusion}

According to the formulas (1) and (2) and data for Saint-Petersburg, it can be concluded that it is necessary to take into account environmental restrictions at all stages of the life cycle of transport facilities (investment justification, design, manufacture, construction, reconstruction, maintenance, dismantling), as well as in assessing the prospects for the development of the transport system. These restrictions are particularly important in urban areas.

Only innovative measures can lead to reduction of pollutions caused by vehicle, to rational consumption of natural resources, protection of the atmosphere and watercourses, soil, residential areas and animal habitats from the negative impact of the transport complex. 


\section{References}

1. N.I. Fedunets, S.V. Frolov, Mining informational and analytical bulletin, S2, 9-16 (2009)

2. T.V. Nazmeeva, N.I. Vatin. Magazine of Civil Engineering, 2 (62), 92-101 (2016)

3. M. Ibatov, I. Pak, B. Askarov, T. Sarsembaev, V. Shalaev, Modern problems of science and education, 3, 42 (2013)

4. N.S. Zakharov, A.A. Panfilov, G.V. Shtein, The influence of seasonal conditions on emissions of heavy metals during the operation. TSU, 113 (2016)

5. E.I. Gumerova, O.S. Gamayunova, S. Pospelova. MATEC, 53, 01021 (2016)

6. V.A. Molodtsov, A.A. Guskov, Determination of emissions of pollutants from vehicles: method. instructions. TSTU, 22 (2014)

7. M.P. Fedorov, V.V. Elistratov, V.I. Maslikov, A.N. Chusov, A.S. Savvichev. Hydropower status and outlook in Poland and Europe Abstracts of Conference Contributions, 17-18 (2016)

8. M. Zubkova, V. Maslikov, D. Molodtsov, A. Chusov, V. Zhazhkov, A. Stroganov. MATEC Web of Conferences, 04004 (2016)

9. M.R. Petrichenko, E.V. Kotov, D.V. Nemova, D.S. Tarasova, V.V. Sergeev. Magazine of Civil Engineering, 1 (77), 130-140 (2018)

10. M.R. Petritchenko. Physics and Mathematics, 1, 1-11 (2016)

11. M.R. Petrichenko, D.W. Serow. Proceedings of the 3rd International Conference on Optimization and Analysis of Structures, 86-91 (2015)

12. E.I. Gumerova, O.S. Gamayunova. Construction of Unique Buildings and Structures, 7 (46), 7-16 (2016)

13. O.S. Gamayunova, E.I. Gumerova. Procedia Engineering, 165, 1637-1642 (2016)

14. A. Hirkovskis, D. Serdjuks, V. Goremikins, L. Pakrastins, N.I. Vatin. Magazine of Civil Engineering, 5 (57), 86-96 (2015)

15. I.N. Priadko, V.P. Mushchanov, H. Bartolo, N.I. Vatin, I.N. Rudnieva. Magazine of Civil Engineering, 5 (65), 27-41 (2016)

16. Saknite T., Serdjuks D., Goremikins V., Pakrastins L., Vatin N.I. Magazine of Civil Engineering, 4 (64), 26-39 (2016)

17. A.V. Chechevichkin, N.I. Vatin, V.V. Samonin, M.A. Grekov. Magazine of Civil Engineering, 8 (76), 201-213 (2017)

18. R. Jaikumar, S.M. Shiva Nagendra, R. Sivanandan. Transportation Research Part D: Transport and Environment, 54, 397-409 (2017)

19. L. Weerasundara, M. Vithanag. International Journal of Energy, Environment and Economics, 4-5, 603-621 (2015)

20. R.J. Rossi, D.J. Bain, G. Darrel Jenerette, L.W. Clarke, K. Wilson. Biogeochemistry, 1-3, 131-144 (2015)

21. B. Li, S.S.H. Ho, Y. Xue, Y. Huang, L. Wang, W. Dai, H. Zhong, J. Cao, Y. Cheng, S. Lee. Atmospheric Environment, 161, 1-12 (2017)

22. W.J. Requia, M. Ferguson, M.D. Adams, A. Arain, P. Koutrakis, W.C. Lee. The Science of the Total Environment, 599-600, 1813-1822 (2017)

23. M. Petrichenko, D. Nemova, E. Reich, F. Khayrutdinova, V. Olshevskyi, R. Schilling, S. Subbotina. MATEC Web of Conferences, 02007 (2016)

24. S. Hasheminassab, N. Daher, C. Sioutas, B.D. Ostro. Environmental Pollution, 193, 54-64 (2014)

25. W.J. Requia, M.D. Adams, P. Koutrakis, H.L. Roig, C.M. Santos. Environmental Research, 150, 452-460 (2016)

26. M. Petrichenko, D. Nemova, E. Reich, S. Subbotina, F. Khayrutdinova. EPJ Web of Conferences, 10, 02092 (2016) 
27. S. Obiri, Z. Naangmenyele, S.J. Cobbina, F.A. Armah. Environmental Science and Pollution Research, 18, 1166-1173 (2011)

28. R. Wu, J. Li, Y. Hao, Y. Li, L. Zeng, S. Xie. The Science of the Total Environment, 560-561, 62-72 (2016)

29. K.O. Owoade, F.S. Olise, L.T. Ogundele, O.G. Fawole, P.K. Hopke, O.O. Adewole. Atmos. Pollut. Res., 5, 843-857 (2016)

30. A.N. Chusov, V.I. Maslikov, D.V. Molodtsov, O.A. Manukhina. Adv. Intell. Syst., 692, 1046-1054 (2018)

31. N.I. Vatin, A.Y. Ivanov, Y.L. Rutman, S.A Chernogorskiy. Magazine of Civil Engineering, 8 (76), 67-83 (2017)

32. S.V. Korniyenko, N.I. Vatin, A.S. Gorshkov. Magazine of Civil Engineering, 4 (64), 10-25 (2016) 